\section{Editor-in-Chief \\ Barbara McLain - (retired Prof.) \\ University of Hawaii, USA}

The Israeli Journal of Aquaculture (IJA) is an interdisciplinary journal that is dedicated to sharing new research and tested applications of aquaculture

The IJA is devoted to scholarly articles for improved aquaculture practices and related industries

The IJA is a peer-reviewed, open-access, electronic journal

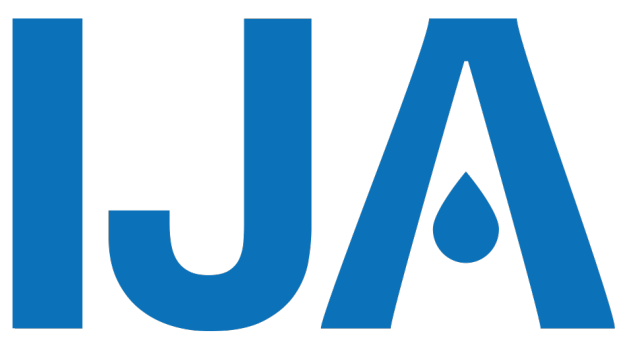

\section{The () Israeli Journal of Aquaculture}

An interdisciplinary online Open Access scientific journal

Published by the

\section{AquacultureHub}

A non-profit organization 501c3

http://www.aquaculturehub.org

in partnership with the

\section{University of Hawaii at Manoa} Library

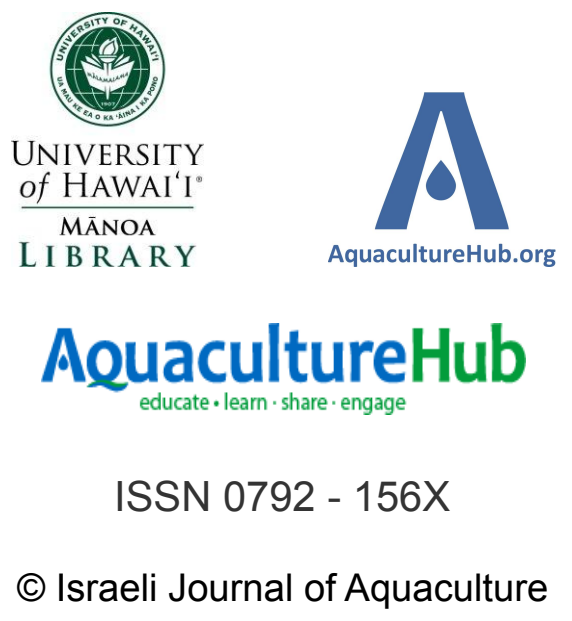




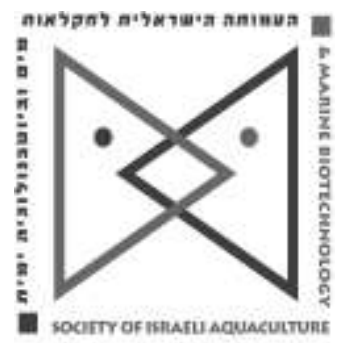

The IJA appears exclusively as a peer-reviewed on-line open-access journal at http://www.siamb.org.il.

To read papers free of charge, please register online at registration form.

Sale of $I J A$ papers is strictly forbidden.

\title{
Using Microsatellites to Assess Genetic Variation in a Selective Breeding Program of Chinese Bay Scallop (Argopecten irradians irradians)
}

\author{
Shoudu Zhang ${ }^{1,2}$, Li Li ${ }^{1}$, Guofan Zhang ${ }^{1} *$ \\ ${ }^{1}$ Institute of Oceanology, Chinese Academy of Sciences, Qingdao 266071, \\ China \\ ${ }^{2}$ University of Chinese Academy of Sciences, Beijing 100049, China
}

(Received 21.11.12, Accepted 21.1.13)

Key words: Argopecten irradians irradians, selective breeding program, microsatellites, genetic variation

\begin{abstract}
This study aimed to improve our understanding of the genetics of the Chinese bay scallop (Argopecten irradians irradians), one of the most important maricultured shellfish in China. Ten polymorphic microsatellite loci were examined to assess the allelic diversity, heterozygosity, and genetic variation between two domesticated populations selected for fast growth in breeding programs, and their base population. Forty-one alleles were found throughout the loci and the mean number of alleles per locus ranged 3.30-3.50. The average heterozygosity ranged $0.38-0.45$, whereas the polymorphic information content ranged $0.1504-0.7518$. Genetic differences between the three populations were detected based on the number of alleles per locus, effective number of alleles, Shannon index, inbreeding coefficient (Fis), $p$ values, genetic distance, and pairwise Fst values. There was no significant loss of genetic variability in the breeding program but changes in gene frequencies were detectable over the populations, implying that the loci were affected by the pressures of selective culture.
\end{abstract}




\section{Introduction}

The bay scallop, Argopecten irradians irradians Lamarck, is a marine bivalve of considerable economic importance, naturally distributed along the coasts of the Atlantic Ocean and the Gulf of Mexico (Wilbur and Gaffney, 1997). For about one century until the mid 1980s, bay scallops supported large commercial fisheries in Massachusetts, New York, and North Carolina and smaller fisheries in western Florida, USA. However, since then, bay scallop populations have dramatically declined due to large blooms of harmful toxic microscopic algae that cause high mortality (Belding, 1910; Goldberg and Tettelbach, 2008; Mackenzie, 2008). Since the introduction of 26 bay scallop specimens from the USA in 1982, a successful aquaculture industry was founded in China and the bay scallop became one of China's most important aquaculture species (Zhang et al., 1986; Guo et al., 1999). After that, serious problems affected scallop breeders in China, such as increased larvae and juvenile mortality and decreased growth rate (Zhang et al., 1997).

Genetic degradation of commercial Chinese bay scallop stocks was found by comparing mtDNA (Blake et al., 1997) and allozymes (Xue et al., 1999) to wild populations in America. To restore this important commercial species, a new broodstock of 401 individuals was introduced from Virginia and Massachusetts in 1998 and 1999 (Li et al., 2000). The new immigrants quickly replaced the original aging stocks and significantly boosted the industry. But genetic degradation in this hermaphroditic bivalve is a potential threat due to high inbreeding depression caused by self-fertilization (Stiles and Choromanski, 1995) and, in fact, genetic degradation has been identified by microsatellites (Wang et al., 2007).

Most genetically improved aquaculture strains are developed by traditional selective breeding, crossbreeding, and hybridization (Hulata, 2001). Selective breeding is the most effective way to obtain genetic improvement in cultured marine species (Zheng et al., 2006a). Selective breeding in oysters, hard calms, scallops, and other species can improve growth rates and disease resistance. Mass selection was used to increase production of Saccostrea cucullata (Jarayabhand and Thavornyutikarn, 1995), Mercenaria mercenaria (Hadley et al., 1991), and Argopecten ventricosus (Ibarra, 1999; Ibarra et al., 1999). Consequently, a program for selective breeding for fast growth of bay scallop was initiated in the Institute of Oceanology, Chinese Academy of Sciences, Qingdao, China, in March 2002. The Chinese bay scallop was examined by establishing broodstocks for selection, estimating heritability for economically important traits, examining inbreeding depression and heterosis (Zheng et al., 2004, 2006a,b, 2007; Zhang et al., 2007a,b), and developing molecular markers for population genetics (Qin et al., $2007 a, b, c$; Li et al., 2008). Great genetic gains indicated that selection is a promising method for genetic improvement in the bay scallop (Zhang et al., 2008).

Microsatellites are the marker of choice for many types of genetic studies due to their high level of polymorphism, co-dominance, genomic distribution, and small locus size (Wang et al., 2007). Evidence of high genetic load was found in the Pacific oyster, Crassostrea gigas, by comparing the segregation ratios of microsatellite DNA markers at $6 \mathrm{~h}$ and 2-3 months post-fertilization in hybrid families (Launey and Hedgecock, 2001). Genetic variation in four successive mass selection lines of Tasmanian hatchery-produced stocks of Pacific oysters was characterized by allozymes and microsatellite loci (Appleyard and Ward, 2006). In this study, we examined genetic variations between two domesticated populations of Chinese bay scallop from our selective breeding program and their base population.

\section{Materials and Methods}

Sample collection. Fifty individuals were randomly collected from each of three populations: Zhongkehong stock R10, domesticated for 8 years; Zhongke No. 2 stock P10, domesticated for 4 years; and their base population from Jiaonan, China $\left(120^{\circ} 02^{\prime} \mathrm{E}\right.$, $35^{\circ} 80^{\prime} \mathrm{N}$ ). Genomic DNA from the three populations (total 300 individuals) was extracted from ethanol-preserved samples using a Fast200 DNA extraction kit (Fastagen, Shanghai, China) according to the manufacturer's instructions. 
Microsatellite analysis. Ten polymorphic microsatellite loci were selected for polymerase chain reaction (PCR) analysis to detect genetic polymorphism (Zhan et al., 2006; Li et al., 2007). PCR amplifications were carried out in $15-\mu l$ reactions containing $1 \times$ PCR buffer, $0.34 \mu \mathrm{m}$ of each primer, $200 \mu \mathrm{m}$ of each dNTP, $1.5 \mathrm{~mm} \mathrm{MgCl}, 0.5 \mathrm{U}$ Taq polymerase, and about $50 \mathrm{ng}$ of template DNA on a TaKaRa TP600 PCR Thermal Cycler Dice (TaKaRa, Japan). The thermal profile for PCR amplification was 5 min at $94^{\circ} \mathrm{C}, 35$ cycles of $30 \mathrm{~s}$ at $94^{\circ} \mathrm{C}, 30 \mathrm{~s}$ at the primer-specific annealing temperature (Table 1), $30 \mathrm{~s}$ at $72^{\circ} \mathrm{C}$, and a final step for $5 \mathrm{~min}$ at $72^{\circ} \mathrm{C}$. PCR products were separated by electrophoresis on $12 \%$ polyacrylamide gel, sized with Marker DL 2000 (Takara, Dalian, China), and visualized by ethidium bromide stain under a UV transilluminator (BIORAD, USA). Gel-Pro Analyzer software (version 7.0, http://www.mediacy.com) was used to analyze the alleles detected by electrophoresis.

Table 1. Primer sequences, repeat types, and PCR conditions used to study ten microsatellite loci in Chinese bay scallop (Argopecten irradians irradians).

\begin{tabular}{|c|c|c|c|c|}
\hline Locus & Primer sequence $\left(5^{\prime} \rightarrow 3^{\prime}\right)$ & Core sequence & $\begin{array}{c}\text { Optimum } \\
\text { annealing } \\
\text { temperature } \\
\left({ }^{\circ} \mathrm{C}\right)\end{array}$ & $\begin{array}{c}\text { GenBank } \\
\text { accession } \\
\text { no. }\end{array}$ \\
\hline AIMS026 ${ }^{1}$ & $\begin{array}{l}\text { F: CACTTCAGACACAAGTTACCGC } \\
\text { R: TGAACCACCAAAGGTGACGGGG }\end{array}$ & (GAT)6 & 66 & CB416920 \\
\hline AIMS027 ${ }^{1}$ & $\begin{array}{l}\text { F: TGAACTITCCCTCATCGTGTC } \\
\text { R: CACAACTATCAACCTGCCCATC }\end{array}$ & $(\mathrm{CAG}) 5$ & 65 & CB414724 \\
\hline HWAD $190^{2}$ & $\begin{array}{l}\text { F: CACTCGTGGGCGTAAATAG } \\
\text { R: CAAATAAAGGAAGCAACCG }\end{array}$ & (TC)6TT(TC) 21 & 50 & DQ779953 \\
\hline Add $026^{3}$ & $\begin{array}{l}\text { F: CGTTTGGGACTGATTTACC } \\
\text { R: AACCTTTCTATTTCTTGTATTGAC }\end{array}$ & $(\mathrm{TG}) 9 \ldots(\mathrm{TG}) 8$ & 55 & EU623919 \\
\hline Add $050^{3}$ & $\begin{array}{l}\text { F: CATTGTTCGTGGTTCACTG } \\
\text { R: AAAGCAACGGTTGTATTCC }\end{array}$ & $(\mathrm{TG}) 13$ & 54 & EU623932 \\
\hline Aad $171^{3}$ & $\begin{array}{l}\text { F: TATACGCTAAACCATCGCTG } \\
\text { R: AAAAGTTACGAAACACTATCAAAAG }\end{array}$ & $(\mathrm{CA}) 25 \mathrm{CG}(\mathrm{CA}) 11$ & 58 & EU623895 \\
\hline $\operatorname{Add} 032^{3}$ & $\begin{array}{l}\text { F: CTITGAATTGTATITITCGC } \\
\text { R: GTCCAAGGAGGCTITATGC }\end{array}$ & $(\mathrm{TC}) 19$ & 56 & EU623922 \\
\hline Aad071 3 & $\begin{array}{l}\text { F: TACAATGTACTTTACCAGAATAGAC } \\
\text { R: TGCTAATTITCGTTGACC }\end{array}$ & $(A G) 29$ & 54 & EU623847 \\
\hline Asd $223^{3}$ & $\begin{array}{l}\text { F: ATTATTITGTITATACCATAGGAGC } \\
\text { R: CGGTTTAGATTTGGAAGTTTG }\end{array}$ & $(A G) 19$ & 58 & EU623799 \\
\hline Aad092 3 & $\begin{array}{l}\text { F: AATAGAGGATACTTTAGGAAGTTAC } \\
\text { R: GTAAAAATCCTTCAGACATAATC }\end{array}$ & $(A G) 15$ & 60 & EU623859 \\
\hline
\end{tabular}

Statistical analysis. PopGen32 software (version 1.32, available at http:// www.ualberta.ca/ fyeh/popgene.html) was used to analyze the number of alleles per locus $(A)$, the effective number of alleles $\left(A_{e}\right)$, observed $\left(H_{0}\right)$ and expected heterozygosity $\left(\mathrm{H}_{\mathrm{e}}\right)$, Shannon Index (SI), inbreeding coefficient (Fis), statistical significance of Hardy-Weinberg equilibrium (HW), pairwise comparison of allele frequency among all the populations (Hartl and Clark, 1997) for each locus, genetic distance ( $D_{C}$; Nei, 1978), and cluster analysis. Population pairwise Fst values based on the number of different alleles and allele frequencies were calculated using GenePop software version 3.4 (Raymond and Rousset, 1995). Polymorphism information content (PIC), a measure of locus polymorphism, was estimated using the formula of Botstein et al. (1980). Cluster analysis of the three populations was computed using the unweighted pair group method with arithmetic mean (UPGMA) in PopGene 32 (v. 1.32).

\section{Results}

Genetic diversity. Forty-one alleles were identified in the ten microsatellite loci from the 300 individuals (Table 2). The number of alleles per locus (A) ranged 2-6 (avg 3.4), whereas the effective number of alleles per locus $\left(A_{e}\right)$ ranged 1.1959-4.6642 (avg 2.33). 
The mean number of alleles per population ranged 3.3-3.5 and the allele size ranged 100-300 bp. The Shannon Index (SI) ranged 0.3025-1.5757, with an average for all loci in all populations of $0.8961 \pm 0.3427$. The polymorphism information content (PIC) at each locus ranged $0.1504-0.7518$, with an average of $0.4571 \pm 0.1622$. There were significant differences $(p<0.05)$ in average heterozygosis among the three populations. Eleven of the 30 population-locus cases ( 3 populations $\times 10$ loci) significantly deviated from the Hardy-Weinberg (HW) equilibrium $(p<0.01)$. While departure from the HardyWeinberg equilibrium was observed in every population and in most loci, the R10 population had the highest frequency of deviation.

Table 2. Number of alleles $(A)$, effective number of alleles $\left(A_{e}\right)$, observed heterozygosity $\left(H_{0}\right)$, expected heterozygosity $\left(\mathrm{H}_{\mathrm{e}}\right)$, Shannon Index (SI), inbreeding coefficient (Fis), probability value of Hardy-Weinberg equilibrium (HW), and polymorphism information content (PIC) at ten microsatellite loci surveyed in two populations from a selected breeding program (R10, P10) and their base population of the Chinese bay scallop, Argopecten irradians irradians $(n=50)$.

\begin{tabular}{|c|c|c|c|c|c|c|c|c|c|c|c|c|}
\hline \multicolumn{13}{|c|}{ Locus } \\
\hline \multicolumn{2}{|c|}{ Population } & AIMS026 & AIMS027 & Add026 & HWAD190 & Add050 & Aad171 & Add032 & Aad071 & Asd223 & Aad092 & $\begin{array}{c}\text { Mean of all } \\
\text { loci }\end{array}$ \\
\hline \multirow{8}{*}{ R10 } & $A$ & 4 & 3 & 5 & 4 & 3 & 4 & 2 & 2 & 3 & 3 & $3.30 \pm 0.95$ \\
\hline & $A_{e}$ & 2.8043 & 1.227 & 3.1368 & 3.0562 & 2.145 & 2.426 & 1.9992 & 1.7241 & 1.8362 & 1.9077 & $2.23 \pm 0.62$ \\
\hline & $\mathrm{H}_{\mathrm{o}}$ & 0.4800 & 0.1800 & 0.4400 & 0.4000 & 0.3000 & 0.3600 & 0.6600 & 0.2400 & 0.3600 & 0.3800 & $0.38 \pm 0.13$ \\
\hline & $\mathrm{H}_{\mathrm{e}}$ & 0.6499 & 0.1869 & 0.6881 & 0.6796 & 0.5392 & 0.5937 & 0.5048 & 0.4242 & 0.4600 & 0.4806 & $0.52 \pm 0.15$ \\
\hline & SI & 0.3944 & 1.2784 & 1.1641 & 0.8908 & 1.0113 & 0.6929 & 0.6109 & 0.6862 & 0.8338 & 0.8739 & $0.84 \pm 0.26$ \\
\hline & Fis & 0.2540 & 0.0270 & 0.3541 & 0.4055 & 0.4380 & 0.3875 & -0.3205 & 0.4286 & 0.2095 & 0.2013 & $0.24 \pm 0.24$ \\
\hline & $\mathrm{HW}^{*}$ & 0.000025 & 0.465823 & 0.000136 & 0.000000 & 0.000000 & 0.001017 & 0.028151 & 0.001844 & 0.358793 & 0.131811 & - \\
\hline & PIC & 0.5861 & 0.1769 & 0.6267 & 0.6039 & 0.4621 & 0.5179 & 0.3749 & 0.3318 & 0.3604 & 0.4288 & $0.45 \pm 0.14$ \\
\hline \multirow{8}{*}{ P10 } & $A$ & 4 & 2 & 5 & 6 & 4 & 2 & 3 & 3 & 2 & 4 & $3.50 \pm 1.35$ \\
\hline & $A_{e}$ & 2.4594 & 1.4188 & 3.2852 & 4.1528 & 2.0912 & 1.1959 & 2.5316 & 1.9026 & 1.6756 & 2.1322 & $2.28 \pm 0.89$ \\
\hline & $\mathrm{H}_{\mathrm{o}}$ & 0.4600 & 0.2800 & 0.7400 & 0.6200 & 0.3600 & 0.1800 & 0.4600 & 0.3600 & 0.4000 & 0.4400 & $0.43 \pm 0.16$ \\
\hline & $\mathrm{H}_{\mathrm{e}}$ & 0.5994 & 0.2982 & 0.7026 & 0.7669 & 0.5271 & 0.1655 & 0.6111 & 0.4792 & 0.4073 & 0.5364 & $0.51 \pm 0.18$ \\
\hline & SI & 1.0971 & 0.4714 & 1.3706 & 1.5288 & 0.8691 & 0.3025 & 0.9986 & 0.7307 & 0.593 & 0.973 & $0.89 \pm 0.39$ \\
\hline & Fis & 0.2248 & 0.0515 & -0.0638 & 0.1834 & 0.3101 & -0.0989 & 0.2397 & 0.2411 & 0.0079 & 0.1714 & $0.13 \pm 0.14$ \\
\hline & $\mathrm{HW}^{*}$ & 0.065992 & 0.658557 & 0.043627 & 0.031416 & 0.012018 & 0.511612 & 0.006699 & 0.070308 & 0.898001 & 0.000002 & - \\
\hline & PIC & 0.5437 & 0.2516 & 0.6543 & 0.7199 & 0.4361 & 0.1504 & 0.5270 & 0.3793 & 0.3219 & 0.4810 & $0.45 \pm 0.18$ \\
\hline \multirow{8}{*}{ Base } & A & 5 & 2 & 3 & 5 & 3 & 5 & 2 & 3 & 2 & 4 & $3.40 \pm 1.24$ \\
\hline & $A_{e}$ & 2.3408 & 1.3931 & 1.6404 & 3.4130 & 2.8043 & 4.6642 & 1.9616 & 2.0517 & 1.3423 & 3.2446 & $2.49 \pm 1.05$ \\
\hline & $\mathrm{H}_{\mathrm{o}}$ & 0.4200 & 0.2600 & 0.3600 & 0.6200 & 0.3400 & 0.4600 & 0.3800 & 0.5400 & 0.3000 & 0.7800 & $0.45 \pm 0.16$ \\
\hline & $\mathrm{H}_{\mathrm{e}}$ & 0.5786 & 0.2851 & 0.3943 & 0.7141 & 0.6499 & 0.7935 & 0.4952 & 0.5178 & 0.2576 & 0.6988 & $0.54 \pm 0.18$ \\
\hline & SI & 1.1022 & 0.4559 & 0.7038 & 1.4063 & 1.0610 & 1.5757 & 0.6833 & 0.8521 & 0.4227 & 1.2495 & $0.95 \pm 0.39$ \\
\hline & Fis & 0.2668 & 0.0787 & 0.0779 & 0.1231 & 0.4716 & 0.4145 & 0.2248 & -0.0535 & -0.1765 & -0.1765 & $0.13 \pm 0.22$ \\
\hline & $\mathrm{HW}^{*}$ & 0.026437 & 0.523504 & 0.645819 & 0.210606 & 0.000001 & 0.000000 & 0.096550 & 0.000077 & 0.229949 & 0.040744 & - \\
\hline & PIC & 0.5301 & 0.2424 & 0.3531 & 0.6682 & 0.5673 & 0.7518 & 0.3701 & 0.4397 & 0.2225 & 0.6324 & $0.48 \pm 0.18$ \\
\hline
\end{tabular}

* Significant $p$ values for Hardy-Weinberg equilibrium are in bold

Genetic variation. Pairwise population comparisons of allele frequencies revealed that 23 of the 30 pairs significantly differed, even after Bonferroni correction for the significance level of three simultaneous tests $(p<0.003)$. All pairs showed significant heterogeneity of allele frequencies for at least three loci (Table 3 ). Pairwise Fst values ranged 0.1664-0.2571 with significant differences among populations $(p<0.003)$ after Bonferroni correction (Table 4). Further, six cases of observed heterozygosity excess $($ Fis $<0)$ were observed in all populations (Table 2$)$. The largest genetic distance $(0.5048)$ was observed between R10 and the base population, while the smallest genetic distance $(0.2560)$ was observed between P10 and the base population (Table 4 ). The neighborjoining tree generated from the $D_{C}$ values is shown in Fig. 1 . The three populations fell into three clusters that corresponded to the period of domestication. 
Table 3. Pairwise comparisons of allele frequencies between two selectively bred populations of Chinese bay scallop (R10 for 8 years and P10 for 4 years) and their base population at ten microsatellite loci.

\begin{tabular}{|c|c|c|c|c|c|c|c|c|c|}
\hline Locus & Population & $R 10$ & $P 10$ & Base & Locus & Population & $R 10$ & P10 & Base \\
\hline & R10 & - & & & & R10 & - & & \\
\hline \multirow[t]{3}{*}{ AIMS026 } & P10 & $0.00000 *$ & - & & Aad171 & P10 & $0.00000 *$ & - & \\
\hline & Base & $0.00000 *$ & 0.76796 & - & & Base & $0.00000 *$ & $0.00000 *$ & - \\
\hline & $\mathrm{R} 10$ & - & & & & $\mathrm{R} 10$ & - & & \\
\hline \multirow[t]{3}{*}{ AIMS027 } & P10 & $0.00000 *$ & - & & Add032 & P10 & $0.00000 *$ & - & \\
\hline & Base & $0.00000 *$ & 1.00000 & - & & Base & 0.32417 & $0.00007 *$ & - \\
\hline & $\mathrm{R} 10$ & - & & & & $\mathrm{R} 10$ & - & & \\
\hline \multirow[t]{3}{*}{ Add026 } & P10 & $0.00000 *$ & - & & Aad071 & P10 & $0.00000 *$ & - & \\
\hline & Base & $0.00000 *$ & $0.00000 *$ & - & & Base & $0.00000 *$ & 0.12857 & - \\
\hline & R10 & - & & & & R10 & - & & \\
\hline \multirow[t]{3}{*}{ HWAD190 } & P10 & $0.00000 *$ & - & & Asd223 & P10 & $0.00000 *$ & - & \\
\hline & Base & $0.00000 *$ & 0.00711 & - & & Base & $0.00000 *$ & 0.03992 & - \\
\hline & R10 & - & & & & R10 & - & & \\
\hline \multirow[t]{2}{*}{ Add050 } & P10 & $0.00000 *$ & - & & Aad092 & P10 & 0.15424 & - & \\
\hline & Base & $0.00000 *$ & 0.00000* & - & & Base & $0.00000 *$ & $0.00012 *$ & - \\
\hline
\end{tabular}

*Significant after Bonferroni correction $(p<0.01-0.03)$. Probability values of homogeneity of allelic frequency distributions ( $P$ ) estimated by a test analogous to the Fisher's exact test in the Markov-chain method are shown; wide significance levels were applied using the sequential Bonferroni technique (Rice, 1989; $k=3$ ).

Table 4. Nei (1978) unbiased measures of genetic distance (below diagonal) and Fst values (above diagonal) among three populations of Chinese bay scallop.

\begin{tabular}{lccc}
\hline Population & $R 10$ & $P 10$ & Base \\
\hline R10 & & $0.2368^{*}$ & $0.2571^{*}$ \\
P10 & 0.4096 & & $0.1664^{*}$ \\
Base & 0.5048 & 0.2560 & \\
\hline
\end{tabular}

Wide significance levels were applied using the sequential Bonferroni technique (Rice, 1989; $k=3$ ). *Significant after Bonferroni correction $(p<0.01 / 3)$

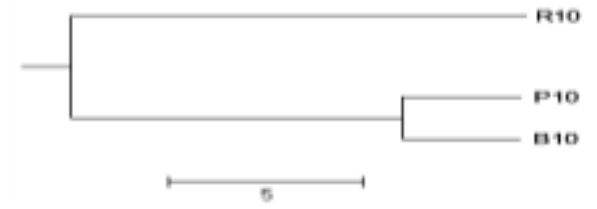

Fig. 1. Cluster analysis of two selectively bred populations of Chinese bay scallop (R10 for 8 years and P10 for 4 years) and their base population (B10) using the unweighted pair group method with arithmetic mean (UPGMA) in PopGene 32 (v. 1.32).

\section{Discussion}

The bay scallop is China's most successful industry built on an introduced species. However, high mortalities and slow growth rates eventually emerged in the small initial population that was maintained in artificial hatcheries and lacked a natural habitat. Bay scallop is simultaneously hermaphrodite and heterosexual. Thus, self-fertilization is common during seed production in the hatchery and this may have caused the high level of inbreeding depression detected in these stocks (Zheng et al., 2007). Selective breeding is widely used for bivalves. To avoid repeating past mistakes, we initiated a selective breeding program in new wild stock introduced from America in 1998 and 1999. In the program, F2 of the imported wild stock was used as a base population from which a strain named Zhongkehong (R10) was domesticated for fast growth for 8 years and a strain named Zhongke No. 2 (P10) was domesticated for fast growth for 4 years. The Zhongkehong strain is cultured on a large scale and accounted for over $60 \%$ of China's bay scallop production in 2012 (unpublished survey data).

As documented by mtDNA and DNA markers, a great proportion of the original genetic variation was lost due to generations of hatchery breeding (Blake et al., 1997; Qin et al., 2007a; Wang et al., 2007). With time, heterozygosity among the populations decreased, moreso in the R10 population than in the P10 and base populations $(p<0.05)$. Although the loss of rare alleles is a meaningful measure of genetic change in hatchery stocks, heterozygosity is more sensitive (Hedgecock and Sly, 1990). There were no significant differences in mean allelic richness among the three populations. Long-term breeding programs aim to achieve a balance between continuous genetic gains and maintenance of adequate levels of genetic variation (Gaiotto et al., 1997). Compared to 
the base population, populations $\mathrm{R} 10$ and $\mathrm{P} 10$ from the selective breeding program showed little reduction in genetic variation. Although a reduction in allele diversity in bay scallop strains was found in a similar microsatellite analysis between wild and hatchery populations of bay scallop, the trend was not significantly digressive (Wang et al., 2007). We believe that genetic variation of the Chinese bay scallop was maintained in some kind of balance, whereas commercial traits were considerably improved by our selective breeding program.

Significant deviations from Hardy-Weinberg (HW) expectations were observed in all populations (11 of the 30 locus tests), as is common (Zouros and Foltz, 1984; Estoup et al., 1995). This type of deviation is most likely caused by selection, admixture of genetically differentiated populations, non-random mating, and null-alleles (Callen et al., 1993; Rousset and Raymond, 1995; Li et al., 2003). Another likely factor is hybridization or mixture between two sub-species from the time of introduction (Zhang et al., 1997). The R10 population had a greater number of loci that deviated from the HW than the P10 or base population; the R10 population is the longer domesticated strain in the selective breeding program. Of concern is the high number of polyallelic loci in the HardyWeinberg disequilibrium for the R10 population, indicating that the population is undergoing great genetic change.

Among the three populations, the Fis value of the R10 population was highest. Inbreeding and the genetic substructure within sampling units can cause high Fis values. Inbreeding is most likely the major factor in our study, inferred from the remarkable increase seen with selection. As self-fertilization is very common in bay scallop, it would be difficult to minimize inbreeding and maintain genetic variability. Inbreeding significantly causes a decline of fitness and genetic variation and affects selective breeding efficiency (Zhang et al., 2005, 2007a; Qin et al., 2007a). More efficient methods are needed to reduce inbreeding during the breeding program. As hermaphroditic marine organisms, bay scallop disperse gametes into flowing sea water that travel during the planktonic larvae stage. But in a hatchery with a limited population size and space, the most effective way to prevent inbreeding is to increase the population size (Qin et al., 2007a).

Population differentiation was detected by traditional Fst (Weir and Cockerham, 1984) and pairwise comparisons of allele frequencies. Significant levels of differentiation were detected among all populations. The Fst between R10 and the base population (B10) was higher than the Fst between P10 and B10. Genetic distances and the neighbor-joining tree topology further describe the genetic variation of the domesticated populations. The R10 population was clearly separate from the other populations, while the P10 population was closer to the B10 population in genetic distance.

In conclusion, our study examined the genetic information of two domesticated strains in the Chinese bay scallop selective breeding program and found that the domesticated strains are undergoing genetic drift. Although no significant reduction in genetic diversity was detected, the domesticated strains showed notable genetic differentiation compared to the base population. Such changes may be the result of longterm artificial selection in the inbreeding population. This information allows us to monitor the genetic basis of Chinese bay scallop commercial strains and improve breeding programs. Inbreeding depression in bay scallop cannot be prevented by creating pedigrees or preventing consanguineous mating in commercial hatchery breeding. The only way to reduce inbreeding depression is to increase the effective population size. At least 340 individuals are necessary to maintain adequate genetic variation (Qin et al., 2007a). Further, as it is difficult to balance the contribution of each individual during fertilization, the safer choice is to spawn more seed than necessary.

\section{Acknowledgements}

We thank Ms. Ying Wang, Mr. Lei Liu, Dr. Juan Li, Master Yu Wang, and Mr. Chonglin Li for their help during the study. This research was supported by the National High Technology Research and Development Program (863 program, 2012AA10A410, 2010AA10A401), Mollusc Research and Development Center, CARS, 
Taishan Scholar Program of Shandon, and the Taishan Scholars Climb Program of Shandong.

\section{References}

Appleyard S.A. and R.D. Ward, 2006. Genetic diversity and effective population size in mass selection lines of Pacific oyster (Crassostrea gigas). Aquaculture, 254:148-159.

Belding D.L., 1910. A report upon the scallop fishery of Massachusetts, including the habits, life history of Pecten irradians, its rate of growth, and other facts of economic value. Wright and Potter Printing Co., State Printers, Boston. 150 pp.

Blake S.G., Blake N.J., Oesterling M.J. and J.E. Graves, 1997. Genetic divergence and loss of diversity in two cultured populations of the bay scallop, Argopecten irradians (Lamarck, 1819). J. Shellfish Res., 16:55-58.

Botstein D., White R.L., Sckolnick M. and R.W. Davis, 1980. Construction of a genetic linkage map in man using restriction fragment length polymorphism. Am. J. Hum. Genet., 32(3):314-331.

Callen D.F., Thompson A.D., Shen Y., Phillips H.A., Richards R.I., Mulley J.C. and G.R. Sutherland, 1993. Incidence and origin of "null" alleles in the (AC)n microsatellite markers. Am. J. Hum. Genet., 52:922-927.

Estoup A., Garnery L., Solignac M. and J.M. Cornuet, 1995. Microsatellite variation in honey-bee (Apis mellifera L) populations: hierarchical genetic structure and test of the infinite allele and stepwise mutation models. Genetics, 140:679-695.

Gaiotto F.A., Bramucci M. and D. Grattapaglia, 1997. Estimation of outcrossing rate in a breeding population of Eucalyptus urophylla with dominant RAPD and AFLP markers. Theor. Appl. Genet., 95:842-849.

Goldberg R. and S.T. Tettelbach, 2008. The history and status of bay scallop, Argopecten irradians irradians, populations in Connecticut and New York. J. Shellfish Res. 27:1012-1012.

Guo X.M., Ford S.E. and F.S. Zhang, 1999. Molluscan aquaculture in China. J. Shellfish Res., 18:19-31.

Hadley N.H., Dillon R.T. and J.J. Manzi, 1991. Realized heritability of growth-rate in the hard clam Mercenaria Mercenaria. Aquaculture, 93:109-119.

Hartl D.L. and A.G. Clark, 1997. Principles of Population Genetics. Sinauer Associates, Inc., Sunderland. 542 pp.

Hedgecock D. and F. Sly, 1990. Genetic drift and effective population sizes of hatcherypropagated stocks of the Pacific oyster, Crassostrea-Gigas. Aquaculture, 88:21-38.

Hulata G., 2001. Genetic manipulations in aquaculture: a review of stock improvement by classical and modern technologies. Genetica, 111:155-173.

Ibarra A.M., 1999. Correlated responses at age 5 months and 1 year for a number of growth traits to selection for total weight and shell width in catarina scallop (Argopecten ventricosus). Aquaculture, 175:243-254.

Ibarra A.M., Ramirez J.L., Ruiz C.A., Cruz P. and S. Avila, 1999. Realized heritabilities and genetic correlation after dual selection for total weight and shell width in catarina scallop (Argopecten ventricosus). Aquaculture, 175:227-241.

Jarayabhand $\mathbf{P}$. and $\mathbf{M}$. Thavornyutikarn, 1995 . Realized heritability estimation on growth rate of oyster, Saccostrea cucullata Born, 1778. Aquaculture, 138:111-118.

Launey S. and D. Hedgecock, 2001. High genetic load in the Pacific oyster Crassostrea gigas. Genetics, 159:255-265.

Li Y., Liu W., Xin G., Gu Z., Shao T. and Y. Cao, 2000. Introduction and F1 rearing of the American bay scallop Argopecten irradians irradians Lamarck. Heibei Fish., 2:29-32 (in Chinese with English abstract).

Li G., Hubert S., Bucklin K., Ribes V. and D. Hedgecock, 2003. Characterization of 79 microsatellite DNA markers in the Pacific oyster Crassostrea gigas. Mol. Ecol. Notes, 3:228-232.

Li H.J., Liu X., Hu J.J., Bao Z.M. and G.F. Zhang, 2007. A set of polymorphic microsatellite loci for the bay scallop, Argopecten irradians. Mol. Ecol. Notes, 7:422-424.

Li R.H., Li Q. and R.H. Yu, 2008. A set of polymorphic expressed sequence tag-derived 
microsatellites from the bay scallop, Argopecten irradians irradians, and their transportability in three other scallop species. J. World Aquacult. Soc., 39:138-141.

Li H., Liu X. and G. Zhang, 2012. Development and linkage analysis of 104 new microsatelitte markers for bay scallop (Argopecten irradians ). Mar. Biotechnol., 14:1-9.

Mackenzie C.L., 2008. History of the bay scallop (Argopecten irradians spp.) fishery, Massachusetts through Florida. J. Shellfish Res., 27:1027-1027 (abstract).

Nei M., 1978. Estimation of average heterozygosity and genetic distance from a small number of individuals. Genetics, 89:583-590.

Qin Y.J., Liu X., Zhang H.B. and G.F. Zhang, 2007a. Effect of parental stock size on F1 genetic structure in the bay scallop, Argopecten irradians (Lamarck, 1819). Aquacult. Res., 38:174-181.

Qin Y.J., Liu X., Zhang H.B., Zhang G.F. and X.M. Guo, 2007b. Genetic mapping of size-related quantitative trait loci (QTL) in the bay scallop (Argopecten irradians) using AFLP and microsatellite markers. Aquaculture, 272:281-290.

Qin Y.J., Liu X., Zhang H.B., Zhang G.F. and X.M. Guo, 2007c. Identification and mapping of amplified fragment length polymorphism markers linked to shell color in bay scallop, Argopecten irradians irradians (Lamarck, 1819). Mar. Biotechnol., 9:66-73.

Raymond M. and F. Rousset, 1995. Genepop (Version-1.2) - population-genetics software for exact tests and ecumenicism. J. Hered., 86:248-249.

Rice W.R., 1989. Analysing tables of statistical tests. Evolution, 43:223-225.

Rousset F. and M. Raymond, 1995. Testing heterozygote excess and deficiency. Genetics, 140:1413-1419.

Stiles S. and J. Choromanski, 1995. Inbreeding studies on the bay scallop, Argopecten irradians. J. Shellfish Res., 14:278.

Wang L.L., Zhang H., Song L.S. and X.M. Guo, 2007. Loss of allele diversity in introduced populations of the hermaphroditic bay scallop Argopecten irradians. Aquaculture, 271:252-259.

Weir B.S. and C.C. Cockerham, 1984. Estimating F-statistics for the analysis of population-structure. Evolution, 38:1358-1370.

Wilbur A.E. and P.M. Gaffney, 1997. A genetic basis for geographic variation in shell morphology in the bay scallop, Argopecten irradians. Mar. Biol., 128:97-105.

Xue Q., Shela S., Zhang F. and J. Xiang, 1999. Population genetic structure at allozyme phosphor-glucomutase $P G M$ locus and its related traits in different populations of bay scallop, Argopecten irradians. Oceanol. Limnol. Sinica, 30(4):381-389.

Zhan A.B., Hu J.J., Wang X.L., Lu W., Hui M. and Z.M. Bao, 2006. A panel of polymorphic EST-derived microsatellite loci for the bay scallop (Argopecten irradians). J. Mollus. Stud., 72:436-438.

Zhang F., He Y., Qi L. and L. Sun, 1997. Study on the restoration of cultured bay scallop Argopecten irradians through reintroduction of broodstock. Oceanol. Limnol. Sinica, 28(2):146-152 (in Chinese with English abstract).

Zhang H.B., Liu X., Zhang G.F. and G.Z. Zhang, 2005. Effects of effective population size $(\mathrm{Ne})$ on the $\mathrm{F} 2$ growth and survival of bay scallop Argopecten irradians irradians (Lamarck). Acta. Oceanol. Sinica, 24(4):114-120.

Zhang G., Liu X., Zheng H., Zhang H. and X. Guo, 2007a. Genetics and breeding of the bay scallop Argopecten irradians in China. J. Shellfish Res., 26:1355-1356.

Zhang G., Zheng H., Liu X. and X. Guo, 2007b. Divergent selection for growth within one self-fertilized line of bay scallop Argopecten irradians irradians Lamarck (1819). Aquaculture, 272:S320-S320.

Zhang H.B., Liu X., Zhang G.F. and C.D. Wang, 2008. Production of a base population and its responses to F-1 selection in the bay scallop, Argopecten irradians irradians Lamarck (1819). Aquacult. Res., 39:913-918.

Zheng H.P., Zhang G.F., Liu X., Zhang F.S. and X.M. Guo, 2004. Different responses to selection in two stocks of the bay scallop, Argopecten irradians irradians Lamarck (1819). J. Exp. Mar. Biol. Ecol., 313:213-223.

Zheng H.P., Zhang G.F., Liu X.A. and X.M. Guo, 2006a. Sustained response to selection in an introduced population of the hermaphroditic bay scallop Argopecten 
irradians irradians Lamarck (1819). Aquaculture, 255:579-585.

Zheng H.P., Zhang G.F., Guo X.M. and X. Liu, 2006b. Heterosis between two stocks of the bay scallop, Argopecten irradians irradians Lamarck (1819). J. Shellfish Res., 25: 807-812.

Zheng H., Zhang G., Liu X. and X. Guo, 2007. Inbreeding depression for various traits in two stocks of the bay scallop, Argopecten irradians irradians Lamarck (1819). Aquaculture, 272:S320-S321.

Zouros E. and D.W. Foltz, 1984. Possible explanations of heterozygote deficiency in bivalve mollusks. Malacologia, 25:583-591. 